Електронне наукове фахове видання "Ефективна економіка" включено до переліку наукових фахових видань України з питань економіки (Категорія «Б», Наказ Міністерства освіти і науки України від 11.07.2019 № 975) www. economy.nayka.com.ua | № 4, $2020 \mid 30.04 .2020$ p.

DOI: $\underline{10.32702 / 2307-2105-2020.4 .92}$

УДК 658.8

О. П. Бутенко,

к. е. н., доцент, доцент кафедри менеджменту та публічного адміністрування, Харківський національний університет будівництва та архітектури, м. Харків ORCID ID: 0000-0002-2151-8410

Н. В. Опікунова,

старший викладач кафедри менеджменту та публічного адміністрування, Харківський національний університет будівництва та архітектури, м. Харків

ORCID ID: 0000-0003-3789-7010

A. С. Гончарова,

магістрант, кафедри менеджменту та публічного адміністрування, Харківський національний університет будівництва та архітектури, м. Харків ORCID ID:0000-0001-8678-8553

\title{
СИНХРОМАРКЕТИНГ: СУТНІСТЬ, МЕТОДИ ТА КОМПЕНСАТОРНІ ІНСТРУМЕНТИ
}

\author{
A. Butenko \\ PhD in Economics, Associate Professor, \\ Associate Professor of the Department of Management and Public Administration \\ Kharkiv National University of Construction and Architecture, Kharkiv, Ukraine \\ N. Opekunova \\ Senior Lecturer of the Department of Management and Public Administration \\ Kharkiv National University of Construction and Architecture, Kharkiv, Ukraine \\ A. Goncharova \\ Master student of the the Department of Management and Public Administration \\ Kharkiv National University of Construction and Architecture, Kharkiv, Ukraine
}

\section{SINHROMARKETING: ESSENCE, METHODS AND COMPENSATORY INSTRUMENTS}

Інструменти та методи синхромаркетингу призначені для зміщення структури попиту так, щзоб вона більше підходила для ідеальної структури пропозиції. Тому знання про методи визначення і вимірювання сезонних коливань, методи прогнозування попиту та шляхи вирімення проблем пов'язаних із залежністю від сезону є дуже важливими.

У дослідженні встановлені причини змін споживчого попиту, які потребують застосування інструментів синхромаркетингу. Також визначені чинники сезонних коливань $i$ види виробничої діяльності підприємств, які залежать від впливу сезонних коливань, щзо дозволило визначити завдання які відносяться до кожного зазначеного напряму $i$ забезпечують основну частину доходу підприємства та залежать від сезонних коливань. Наявність динамічних коливань попиту вимагають від підприємств знань та умінь використовувати наукові методи аналізу сезонності. Для иього у роботі розглянуті методи вивчення сезонності та прогнозування попиту для потреб маркетингу, які трунтуються, на статистичних даних, щуо не потребують особливої попередньої їх обробки, так $i$ на 
завчасному визначенні тендениії розвитку сезонних коливань, подальшому їх розрахунку та кількісному їх вимірі. Саме методи иієї групи мають можливість враховувати неииклічні коливання, які належать до групи психологічних факторів, таких як мода, традииіi, наслідування. Таким чином, встановлено, щь синхромаркетинг дозволяє упорядкувати внутрішню діяльність компанії з ї̈ маркетинговою діяльністю в умовах хаотичної чи ииклічної мінливості ринку. Синхромаркетинг дозволяє заздалегідь спланувати діяльність підприємства так, щоб запобігти або компенсувати змінний попит на ринку та згладити його коливання в часі.

Synchromarketing tools and techniques are designed to shift the structure of demand so that it is more suitable for the ideal structure of supply. Therefore, knowledge about the methods for determining and measuring seasonal fluctuations, methods for forecasting demand and ways to solve problems associated with season dependence are very important.

The purpose of the article is to study the factors of seasonal fluctuations for various reasonson, to determine the types of production activities of enterprises that depend on the influence of seasonal fluctuations, to consider methods for studying seasonality and forecasting demand, as well as to definitions of compensatory elements of synchromarketing to ensure sustainable indicators of business.

The reasons for changes in consumer demand requiring the use of synchromarketing were identified in the work. Factors of seasonal fluctuations and types of production activities of enterprises, which depend on the influence of seasonal fluctuations, were also investigated, defined tasks that relate to each specified direction and provide the bulk of the income of the enterprise and depend on seasonal fluctuations. The presence of dynamic fluctuations in demand require enterprises to have knowledge and skills to use scientific methods for analyzing seasonality. To do this, the work considers methods for studying seasonality and demand forecasting for marketing needs, based on statistical data that does not require special preliminary processing, and on the early determination of the development trend of seasonal fluctuations, their further calculation and quantitative measurement. It is the methods of this group that are able to take into account noncyclical fluctuations, which belong to the group of psychological factors, such as fashion, traditions, imitations.

Thus, it was found that synchromarketing allows you to streamline the internal activities of the company with its marketing activities in conditions of chaotic or cyclical market volatility. Synchromarketing allows you to pre-plan the activities of the enterprise so as to prevent or compensate for the variable demand in the market and smooth out its fluctuations over time.

Ключові слова: синхромаректинг; компенсаторні інструменти; методи прогнозування попиту; методи визначення і вимірювання сезонних коливань.

Keywords: sinchromarketing; compensatory instruments; demand forecasting methods; methods for the determination and measurement of seasonal fluctuations.

Постановка проблеми та її зв'язки з науковими чи практичними завданнями. Діяльність більшості підприємств характеризується залежністю від сезонності. IIÏ вплив може бути високий, середній чи низький у залежності від виду діяльності підприємства, але він завжди викликає неузгодженість дій між оперативними процесами та маркетинговою діяльністю. Сезонність притаманна майже всім виробникам не тільки за регіональною ознакою (курорти, туристичні місця), але й у залежності від виду продукції чи послуг які виробляються або надаються, а також притаманна високотехнологічним галузям змушуючи їх координувати роботу із постачальниками та споживачами. Тому керівництву потрібно володіти певними навичками та знаннями інструментів, що діють у ситуаціях із високим попитом на продукцію чи послуги і відповідними навичками у ситуаціях із низьким попитом та вміти їх передбачати. Також, важливе розуміння впливу сезонних факторів на споживання та виробництво як можливості прогнозування ефективної діяльності підприємства. Відомим методом збалансування попиту та пропозиції є використання інструментів синхромаркетингу, які надають можливість збалансувати операційну діяльність підприємства 3 його маркетинговою діяльністю в умовах циклічних змін кон’юнктури ринку. 
Аналіз останніх досліджень і публікацій. Наразі концептуальні положення синхромаркетингу чітко визначені у роботах як закордонних та і вітчизняних науковців, таких як С. Шейнбаум [1], Чинг-Тер та СяоЦзин [2], К. Розер [3], Ф. Котлер, Г.Армстронг, Д. Сондерс, В. Вонг [4], В. В. Немченко, В. С. Швагірева, О. С. Тицька, Т. В. Третяк [5]. У роботах зазначених авторів акцентується увага на важливості для керівників розуміння впливу сезонних факторів на зміну попиту, як можливості успішно використовувати його у своїх інтересах. Узагальнюючи думку вчених, можна зазначити основні завдання, які вирішує синхромаркетинг, як аналіз споживчого ринку і причин змін споживчого попиту, прогнозування ринкових тенденцій, введення компенсаторних елементів маркетингу та їх корегування, а також перебудова бізнес-процесів підприємства відповідно до потреб ринку.

Виділення невирішених частин загальної проблеми. Спираючись на основні завдання синхромаркетингу пропонується детальніше розглянути та систематизувати його компенсаторні інструменти які б згладжували коливання попиту, дослідити методи вивчення сезонності та методи прогнозування попиту для потреб маркетингу, що у сукупності також сприяють узгодженню бізнес-процесів 3 маркетинговою діяльністю.

Метою статті є дослідження факторів сезонних коливань за різними ознаками, визначення видів виробничої діяльності підприємств, які залежать від впливу сезонних коливань, розгляд методів вивчення сезонності та прогнозування попиту, а також, визначення компенсаторних елементів синхромаректингу для забезпечення стійких показників бізнесу.

Виклад основного матеріалу дослідження. Синхромаркетинг є видом ринкової діяльності, який дозволяє гнучко реагувати на швидко мінливу ринкову кон'юнктуру [5]. Причини зміни ринкової кон'юнктури мають різну природу. Авторами пропонується виділити причини при яких застосовується синхромаркетинг та встановити його завдання (рис.1).

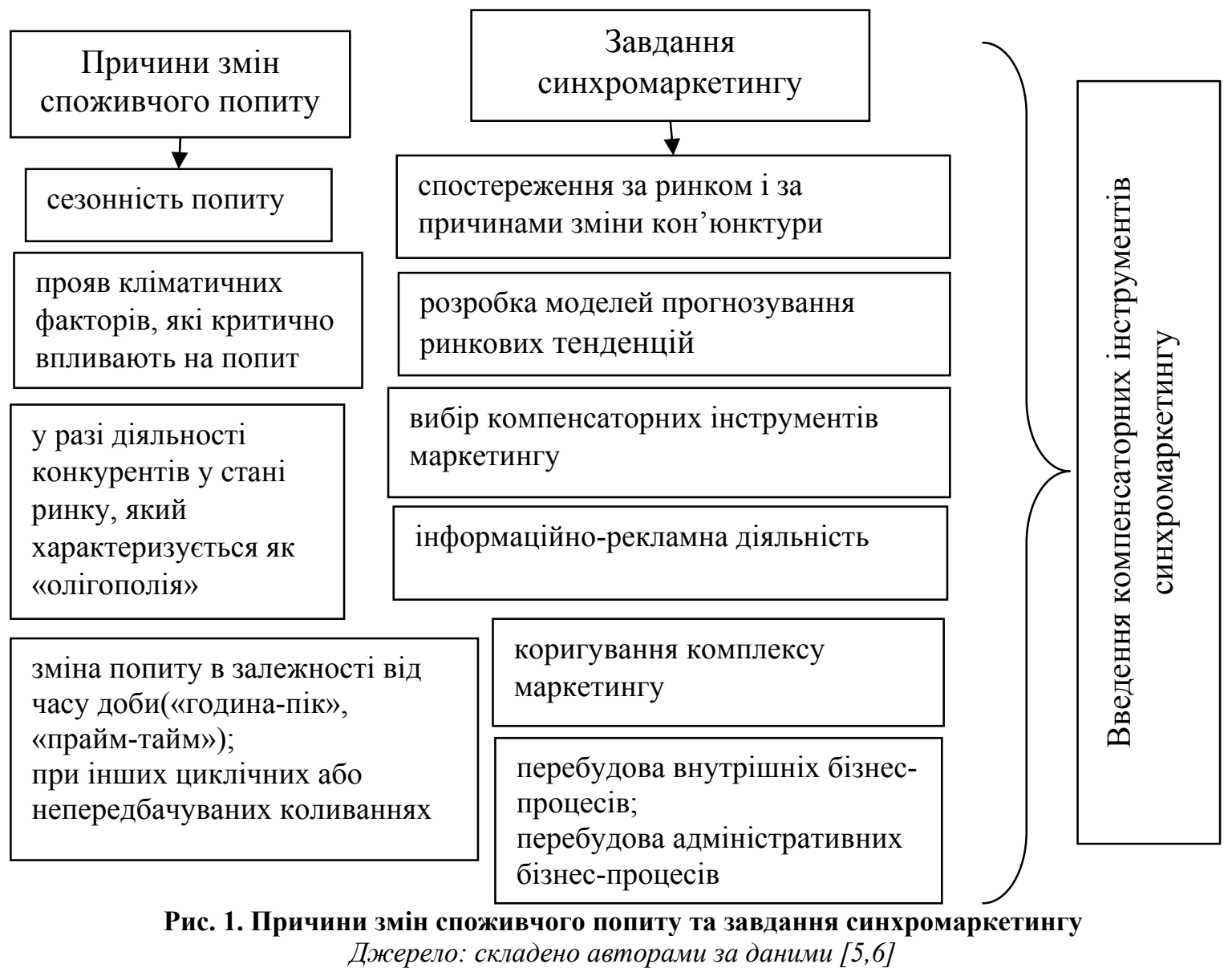

У свою чергу, до економічних факторів сезонних коливань відноситься структура споживання товарів і послуг, формування платоспроможності попиту за допомогою пропозиції. До демографічних факторів відноситься диференційований попит за статевим складом та іншими ознаками. Психологічні фактори складаються $з$ традицій, моди, наслідування. У свою чергу, матеріально-технічні складаються з розвитку мережі розміщення, харчування, транспорту, культурно-оздоровчого обслуговування, а технологічним фактором є комплексний підхід у наданні якісних послуг [7].

Стосовно другого питання, визначення видів виробничої діяльності підприємств, які залежать від впливу сезонних коливань, можна виділити такі види виробничої діяльності [8]: 
- . маркетингова діяльність, яка вивчає ринок товарів і $є$ важливим напрямом діяльності підприємства на ринку. Ії̈ завданнями є аналіз ринку, дослідження рівня конкурентоспроможності продукції чи послуги та рівня ціни, спостереження за зміною смаків споживачів, моніторинг каналів руху товару, обстеження мікро- та макро- середовища підприємства;

- інноваційна діяльність, грунтується на науково-дослідній, дослідно-конструкторській діяльності, впровадженні у практику нововведень різних видів, формування інвестиційної політики;

- виробнича діяльність підприємства, завданнями якої $\epsilon$ наступне: забезпечення випуску необхідного обсягу продукції та номенклатури продукції, відповідно до вимог ринку; визначення маркетингової політики, оптимізація виробничих можливостей та регулювання виробничої потужності;

- комерційна діяльність, завданнями якої $\epsilon$ дієва реклама та ефективний збут продукції, стимулювання покупців. Від організації та якості комерційної діяльності залежить величина одержуваного прибутку;

економічна діяльність підприємства, що складається зі стратегічного та тактичного планування, обліку і звітності, ціноутворення, системи нарахування заробітної плати, ресурсного та фінансового забезпечення виробництва тощо. Економічна діяльність регулює всі елементи системи господарювання підприємства.

Зазначені види діяльності підприємства відносяться до основної діяльності, пов'язаної з виробництвом і реалізацією продукції і забезпечують основну частину його доходу та залежать від сезонних коливань.

Як було зазначено вище, сезонні коливання, які повторюються у певні періоди, змінюють комерційні показники у ці ж проміжки часу. Завдяки цій циклічності можна провести розрахунки відповідних середніх значень, або медіан, які характеризують сезонні коливання. Динамічні сезонні коливання потрібно вимірювати та аналізувати для прийняття відповідних рішень 3 мінімізації негативного впливу коливань.

Відповідно до третього завдання дослідження визначені методи аналізу сезонності, які поділяються на дві групи. Перша група складається з методів розрахунку простої середньої, методу знаходження відносних чисел та методу У. Персонса. За допомогою зазначених методів можна визначити та виміряти сезонність використовуючи статистичні дані, без особливої попередньої їх обробки.

Сутність методів які утворюють другу групу полягає у завчасному визначенні основної тенденції розвитку сезонних коливань, потім їх розрахунку та кількісному їх вимірі. Загальна тенденція може визначатися різними способами в залежності від форми зв'язку між динамікою часу та рівнями коливання. Методами визначення тенденцій сезонних коливань $є$ метод механічного вирівнювання, метод аналітичного вирівнювання і метод ковзної (рухомої) середньої. Методи визначення сезонних коливань та їх характеристики зведені до табл. 1.

Таблиця 1.

Методи визначення і вимірювання сезонних коливань

\begin{tabular}{|c|c|c|}
\hline $\begin{array}{c}\text { Методи } \\
\text { визначення } \\
\text { сезонних } \\
\text { коливань }\end{array}$ & Сутність методу & Переваги і недоліки методу \\
\hline $\begin{array}{l}\text { Метод простої } \\
\text { середньої [9] }\end{array}$ & 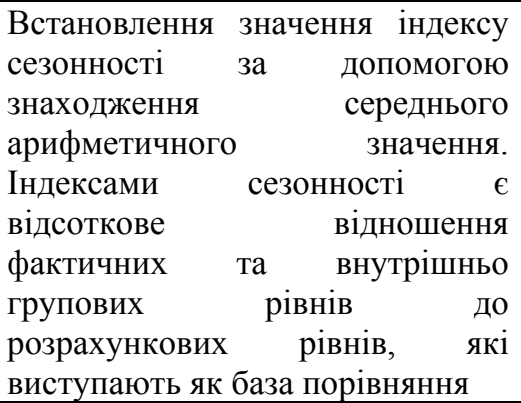 & $\begin{array}{l}\text { Переваги. Простий у використанні, мінімізує } \\
\text { випадкові коливання показників динамічного } \\
\text { ряду. Вірність розрахунків сезонної хвилі } \\
\text { залежить від кількості рівнів ряду та від } \\
\text { характеру іх зміни (чим більше рівнів ряду, } \\
\text { чим більше число років дослідження, тим } \\
\text { точніші будуть результати) } \\
\text { Недоліки. Застосовується не часто, тому що не } \\
\text { враховує вплив загальної тенденції та зміни у } \\
\text { коливаннях протягом досліджуваного періоду }\end{array}$ \\
\hline $\begin{array}{c}\text { Метод } \\
\text { відносних чисел } \\
{[10]}\end{array}$ & 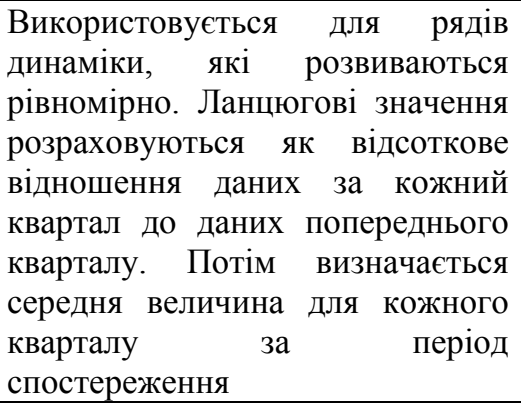 & 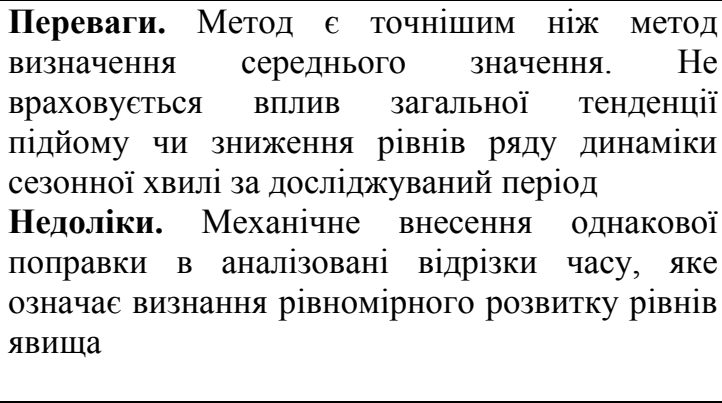 \\
\hline $\begin{array}{c}\text { Метод } \\
\text { У. Персонса [11] }\end{array}$ & $\begin{array}{l}\text { Значення середньої сезонної } \\
\text { хвилі розраховується як значення } \\
\text { медіани } 3 \text { ланцюгових відносин. } \\
\text { Похибка, яка може виникнути, }\end{array}$ & 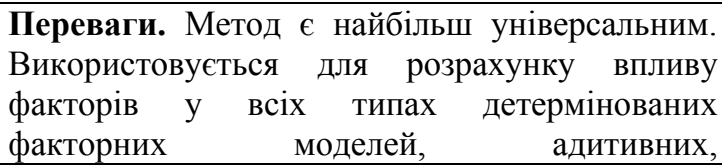 \\
\hline
\end{tabular}




\begin{tabular}{|c|c|c|}
\hline & 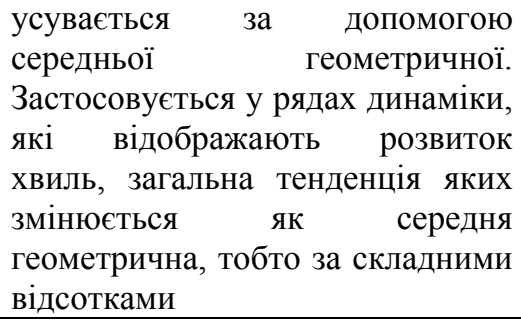 & $\begin{array}{l}\text { мультиплікативних, кратних і змішаних } \\
\text { (комбінованих) } \\
\text { Недоліки. При застосуванні може виникнути } \\
\text { нерозкладний залишок, який приєднується до } \\
\text { числового значення впливу останнього } \\
\text { фактору. Цим буде пояснюватись відмінність у } \\
\text { розрахунках при зміні послідовності } \\
\text { підстановки }\end{array}$ \\
\hline $\begin{array}{c}\text { Метод } \\
\text { механічного } \\
\text { вирівнювання } \\
{[11]}\end{array}$ & 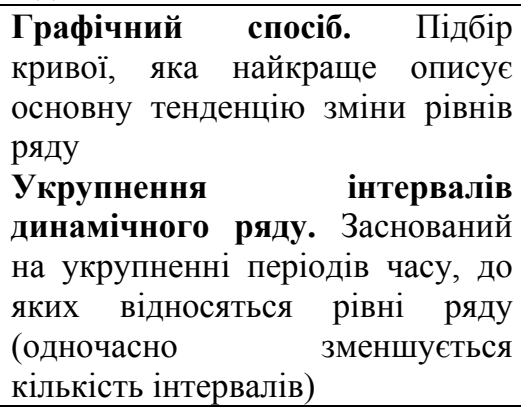 & $\begin{array}{l}\text { Переваги. Простий розрахунок, висока } \\
\text { точність, наочність. Застосовується на практиці } \\
\text { через простоту розрахунку і досить високої } \\
\text { точності і зводиться до використання різних } \\
\text { методів згладжування (фільтрації), укрупнення } \\
\text { інтервалів } \\
\text { Недоліки. При визначенні } \\
\text { приросту вереднього } \\
\text { останній елементи тимчасового ряду, у } \\
\text { результаті чого тенденція виражена неточно }\end{array}$ \\
\hline $\begin{array}{c}\text { Метод ковзної } \\
\text { середньої } \\
\text { (метод Хольта- } \\
\text { Вінтерса) } \\
\text { [11],[12] } \\
\end{array}$ & $\begin{array}{l}\text { Заміна фактичних значень } \\
\text { показника їхніми усередненими } \\
\text { величинами, що мають значно } \\
\text { меншу варіацію, чим вихідні } \\
\text { рівні ряду }\end{array}$ & $\begin{array}{l}\text { Переваги. Простий, легко застосовується, дає } \\
\text { реальну картину довготривалих змін } \\
\text { Недоліки. Вимагає існування відносно } \\
\text { стабільної періодичності тимчасового ряду. }\end{array}$ \\
\hline $\begin{array}{c}\text { Метод } \\
\text { аналітичного } \\
\text { вирівнювання } \\
{[13]}\end{array}$ & $\begin{array}{l}\text { Попереднє визначення та } \\
\text { виключення загальної тенденції } \\
\text { розвитку. Використовується у } \\
\text { рядах динаміки } 3 \text { вираженою } \\
\text { тенденцією збільшення }\end{array}$ & $\begin{array}{l}\text { Переваги. У результаті застосування методу } \\
\text { тенденція зміни показника може бути більш } \\
\text { чітко виражена. Можна аналізувати, } \\
\text { планувати, прогнозувати кількісні зміни, } \\
\text { визначати ступінь впливу окремого фактору на } \\
\text { результат } \\
\text { Недоліки. Відбувається скорочення довжини } \\
\text { динамічного ряду. Метод не дає можливості } \\
\text { кількісно виміряти чинники, які впливають на } \\
\text { зрушення показників }\end{array}$ \\
\hline
\end{tabular}

Економічні процеси важко піддаються прогнозуванню, оскільки на них впливає дуже багато чинників, які зумовлюють численні ризики. Знизити їх повністю, або частково допомагає маркетинговий аналіз, або математичне прогнозування. Результати маркетингового аналізу особливо важливі для прогнозування продажу продукції і послуг, при здійсненні якого використовують різноманітні кількісні та якісні методи, що відкривають різні можливості обгрунтування прогнозних показників.

До найбільш відомих методів прогнозування попиту, які використовуються як інструменти синхромаркетингу, можна віднести методи, які згруповані у табл. 2.

Таблиця 2.

Методи прогнозування попиту, які використовуються у синхромаркетингу

\begin{tabular}{|c|c|}
\hline $\begin{array}{c}\text { Методи прогнозування } \\
\text { попиту }\end{array}$ & Характеристика \\
\hline $\begin{array}{lr}\text { Метод } & \text { Бокса-Дженкінса } \\
\text { ARIMA } & \text { (Інтегрована } \\
\text { модель авторегресії) [14] }\end{array}$ & $\begin{array}{l}\text { стандартизована статистична модель для прогнозування і аналізу часових } \\
\text { рядів. Модель ARIMA відноситься до класу статистичних моделей для } \\
\text { аналізу і прогнозування часових рядів }\end{array}$ \\
\hline Наївний метод $[12,13]$ & $\begin{array}{l}\text { полягає у припущенні однаковості коливань між продажами діючого періоду } \\
\text { та попередніх періодів. Використовується на підприємствах із товарами які } \\
\text { мають постійний попит. Перевагами методу є швидка реакція на зміни } \\
\text { попиту. Недоліком є висока чутливість до випадкових коливань }\end{array}$ \\
\hline $\begin{array}{lr}\text { Метод арифметичного } \\
\text { Згладжування } \quad \text { (метод } \\
\text { довгострокової } & \text { середньої) } \\
{[11,12]} & \end{array}$ & $\begin{array}{l}\text { грунтується на припущенні, що продажі наступного періоду дорівнюють } \\
\text { середньому арифметичному продажів за попередні періоди. До переваг } \\
\text { відноситься згладжування випадкових коливань. Але це може бути і } \\
\text { недоліком, оскільки метод через це не враховує зміни у тенденціях, і реагує із } \\
\text { запізненням на значні коливання попиту }\end{array}$ \\
\hline $\begin{array}{l}\text { Метод сезонної тенденції } \\
{[11,12]}\end{array}$ & $\begin{array}{l}\text { використовує коєфіцієнт сезонної тенденції, тобто прогнозування продажів } \\
\text { товарів сезонного попиту порівнюється } 3 \text { аналогічними минулими періодами } \\
\text { та коригуються за допомогою експертних оцінок }\end{array}$ \\
\hline
\end{tabular}




\begin{tabular}{|l|l|}
\hline $\begin{array}{l}\text { Метод «коєфіцієнтів» } \\
{[11,15]}\end{array}$ & $\begin{array}{l}\text { сутність якого у знаходженні найменшого значення серед усіх періодів } \\
\text { продажів за рік, і задають йому значення коєфіцієнту рівне 1,0, а всі інші } \\
\text { періоди отримують власні значення коефіцієнтів відносно нього }\end{array}$ \\
\hline $\begin{array}{l}\text { Метод прогнозування за } \\
\text { допомогою екстраполяції } \\
\text { Лагранжа [16] }\end{array}$ & $\begin{array}{l}\text { полягає у розширенні висновків, отриманих зі спостережень за однією } \\
\text { те, що при збільшенні прогнозованої дати різко зменшується точність } \\
\text { результату, а також те, що він виконує прогнозування лише для тих товарів, } \\
\text { які мають статистику попередніх продажів }\end{array}$ \\
\hline & Джерело: складено авторами за даними $[13,16,18]$
\end{tabular}

Використання зазначених методів прогнозування попиту та методів визначення сезонних коливань дають змогу керівнику прийняти обгрунтоване рішення щодо вибору компенсаторних інструментів, які пропонує синхромаркетинг. Автори звертають увагу на те, що керівникам потрібно приділяти увагу ситуаціям коли можливий не тільки спад попиту, але i його підвищення, тому що іноді виникають ситуації неспроможності задовольнити високий попит. Зазначені ситуації потребують використання компенсаторних інструментів синхромаретингу. До них класично відносяться інструменти, які зазначені у табл. 3.

Таблиця 3.

Компенсаторні інструменти та заходи синхромаркетингу

\begin{tabular}{|c|c|}
\hline $\begin{array}{c}\text { Компенсаторні } \\
\text { інструменти }\end{array}$ & Заходи синхромаркетингу \\
\hline 1 & 2 \\
\hline Стимулювання & $\begin{array}{l}\text { - цінове стимулювання, тобто продаж товару за спеціальною ціною; } \\
\text { - натуральне стимулювання, наприклад, безкоштовний подарунок; } \\
\text { - стимулювання при обслуговуванні, коли покупцеві полегшують процес купівлі } \\
\text { чи пропонують безкоштовні додаткові послуги; } \\
\text { - диференціація цін, зміна ціни в залежності від піків чи спаду попиту }\end{array}$ \\
\hline $\begin{array}{l}\text { Перемикання } \\
\text { спонукальних } \\
\text { мотивів }\end{array}$ & $\begin{array}{l}\text { - } \quad \text { підсилення естетичних мотивів, привернення уваги на зовнішній вигляд } \\
\text { виробу, пакування; } \\
-\quad \text { мотиви престижу, вплив на певні соціальні групи і при покупці дорогих } \\
\text { брендів, що дозволяє збільшити продаж товарів класу люкс на замовлення; } \\
-\quad \text { утилітарні мотиви, увага реклами на експлуатаційні характеристики товару, } \\
\text { його гарантійний термін, довговічність, можливість швидкого і якісного ремонту } \\
\text { тощо; } \\
\text { - } \quad \text { мотив традиції, обумовлений переважно національно-культурними } \\
\text { особливостями. Дає змогу збільшити продаж сувенірних товарів; } \\
-\quad \text { відкриття спеціалізованих закладів, надання спеціалізованих послуг; } \\
-\quad \text { інтеграція системи попередніх замовлень. Прикладом такого заходу може } \\
\text { слугувати бронювання квитків та номерів готелів через мережу Інтернет } \\
\end{array}$ \\
\hline $\begin{array}{l}\text { Інформаційно- } \\
\text { рекламна } \\
\text { діяльність }\end{array}$ & $\begin{array}{ll}- & \text { постійне покращення комунікацій з клієнтами; } \\
- & \text { поширення знань про товари, послуги та сервісне обслуговування } \\
\text { підприємства; } \\
-\quad \text { формування позитивного іміджу підприємства; } \\
-\quad \text { вплив на процес прийняття рішень щодо купівлі товарів чи отримання } \\
\text { послуг }\end{array}$ \\
\hline $\begin{array}{l}\text { Коригування } \\
\text { комплексу } \\
\text { маркетингу }\end{array}$ & $\begin{array}{ll}\text { використання таких принципів маркетингу: } \\
- & \text { принципу збалансованої комбінації принципів маркетингу; } \\
- & \text { принципу формування конкурентних переваг підприємства; } \\
- & \text { принципу відповідності ресурсів можливостям підприємства } \\
\end{array}$ \\
\hline $\begin{array}{l}\text { Перебудова } \\
\text { бізнес-процесів }\end{array}$ & $\begin{array}{ll}- & \text { визначення бізнес-процесів у яких можливі локальні зміни; } \\
- & \text { перебудова виробничих бізнес-процесів; } \\
- & \text { перебудова адміністративних бізнес-процесів }\end{array}$ \\
\hline
\end{tabular}

Отже, синхромарктенг має у своєму розпорядженні компенсаторні інструменти, які дозволяють згладити коливання попиту, методи прогнозування, які дозволяють його передбачити та методи визначення й вимірювання сезонних коливань, які дозволяють визначити тенденції сезонних коливань та надають можливість їх аналітичного вирівнювання.

Висновок. Інструменти та методи синхромаркетингу призначені для зміщення структури попиту так, щоб вона більше підходила для ідеальної структури пропозиції. Синхромаркетинг надає різні способи розв’язання проблеми неузгодженості структури попиту, що $є$ можливістю для кожного підприємства 
мінімізувати негативний вплив сезонності. Тому знання про методи визначення і вимірювання сезонних коливань, методи прогнозування попиту та шляхи вирішення проблем пов'язаних із залежністю від сезону $\epsilon$ дуже важливими. У роботі встановлені причини змін споживчого попиту, які потребують застосування синхромаркетингу. Також досліджені чинники сезонних коливань і види виробничої діяльності підприємств, які залежать від впливу сезонних коливань, що дозволило визначити завдання які відносяться до кожного зазначеного напряму і забезпечують основну частину доходу підприємства та залежать від сезонних коливань. Наявність динамічних коливань попиту вимагають від підприємств знань та умінь використовувати наукові методи аналізу сезонності. Для цього у роботі розглянуті методи вивчення сезонності та прогнозування попиту для потреб маркетингу, які грунтуються, на статистичних даних, що не потребують особливої попередньої їх обробки, так і на завчасному визначенні тенденції розвитку сезонних коливань, подальшому їх розрахунку та кількісному їх вимірі. Саме методи цієї групи мають можливість враховувати нециклічні коливання, які належать до групи психологічних факторів, таких як мода, традиції та наслідування.

Таким чином, встановлено, що синхромаркетинг дозволяє упорядкувати внутрішню діяльність компанії з її маркетинговою діяльністю в умовах хаотичної чи циклічної мінливості ринку. Також дозволяє заздалегідь спланувати діяльність підприємства так, щоб запобігти або компенсувати змінний попит на ринку та згладити його коливання у часі. Перспективою подальшого розвитку синхромаркетингу може стати поява нових методів та нових компенсаторних інструментів які б відповідали новим викликам техніки та технологій.

\section{Список літератури.}

1. Sheinbaum S. (S., 2014)[Електронний ресурc] / Stephen Sheinbaum // Entrpreneur. - 2014. - Режим доступу до ресурсу: https://www.entrepreneur.com/article/239584

2. Ching-Ter C. A coordination system for seasonal demand problems in the supply chain [Електронний pecypc] / C. Ching-Ter, C. Hsiao-Ching // Applied mathematical modelling. - 2013. - Режим доступу до ресурсу: https://www.sciencedirect.com/science/article/pii/S0307904X12004921

3. Розер К. Надійне виявлення вузьких місць в цеху для ліній потоку за допомогою спостережень за процесом і запасами: обхід вузьких місць / К. Розер, К. Лоренцен, Й. Деуз / Logistics Research. - 2015. - С.1-9

4. Котлер Ф. Введення в маркетинг / Ф. Котлер, Г.Армстронг / в-д Вільямс. - 2007. - 832c.

5. Немченко В. В. Ефективність системи маркетингу на підприємствах виноробної галузі в Україні / В. В. Немченко, В. С. Швагірева, О. С. Тицька, К. В. Третяк // Молодий вчений. - 2014. - № 8(2). - С. 10-12

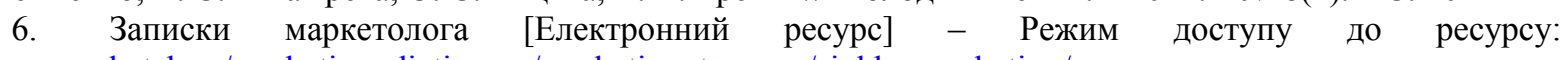
http://www.marketch.ru/marketing_dictionary/marketing_terms_s/sinkhromarketing/.

7 Назарова Г. Г. Сезонность в туризме: проблемы и измерения / Г. Г. Назарова, Д.С. Хакимов / Вісник ДІТБ. - 2001. - № 5. - С. 60-63.

8. Нікітіна I. М., Попова Л. О. Обгрунтування вибору моделі сезонного коригування валового внутрішнього продукту // Статистика України.-2003.- № 4.-С. 20-27.

9. Дяченко Ю. А. Розвиток методів прогнозування динаміки біржових цін на сільськогосподарські товари / Ю. А. Дяченко // Науковий вісник Ужгородського національного університету. - 2018. - С.142-146.

10. Гринюк О. І. Науково-методичні підходи до оцінювання та прогнозування ризиків діяльності нафтогазовидобувних підприємств / О. І. Гринюк. // Вісник Хмельницького національного університету. - 2016. - C. $10-22$.

11. Четвериков Н. С. Статистические исследования: Теория и практика / Н. С. Четвериков. - М.: Наука, 1975. - 388 c.

12. Шевченко Н. Ю. Разработка концептуальных подходов к формированию производственной программы выпуска продукции с учетом предпрогнозного анализа временных рядов / Н. Ю. Шевченко, Л. А. Останкова, М. Ю. Руднев. // ВІСНИК Донбаської державної машинобудівної академії. - 2012. - С. 310313.

13. Ромащенко О. В. Планування та прогнозування доходів та витрат страховиків за методом «Аналітичного вирівнювання» [Електронний ресурс] / О. В. Ромащенко // Проблемы материальной культуры Экономические науки. - 2012. - 2 Режим доступу до ресурсу: http://dspace.nbuv.gov.ua/bitstream/handle/123456789/92337/11-Romashchenko.pdf?sequence=1.

14. Михайлов В. С. Сезонні коливання та календарні ефекти: окремі проблеми теорії і практики статистичного оцінювання / В. С. Михайлов, Ю. І. Прилипко, К. І. Шепель. // Теорія та методологія статистики. - 2012. - №4. - C. 21-26.

15. Бузукова Е. Л. Закупки и поставщики. Курс управления ассортиментом в рознице / Е. Л. Бузукова// под ред. С. Сысоевой. - СПб.: Питер, 2009. — 432 с.

16. Прогнозування соціально-економічних процесів : навчальний посібник / Т. С. Клебанова, В. А. Курзенев, В. М. Наумов та ін. - Х. : ХНЕУ ім. С. Кузнеця, 2015. - 656 с.

\section{References.}

1. Sheinbaum, S. (2014), “7 Tips for Managing a Seasonal Business”, Entrepreneur, [Online], available at: https://www.entrepreneur.com/article/239584 (Accessed 19 April 2020). 
2. Ching-Ter, C. (2013), "A coordination system for seasonal demand problems in the supply chain", Applied mathematical modelling, [Online], available https://www.sciencedirect.com/science/article/pii/S0307904X12004921 (Accessed 19 April 2020).

3. Lorencen, R. K. and Deuz, J. (2015), “Management Part 2 - Improve Bottleneck Planning”, Logistics Research, pp.1-9.

4. Kotler, F. and Armstrong, G. (2007), Introduction to Marketing, Williams, London, UK

5. Nemchenko, V. V. Shvagireva, S. Tizka, O. S. and Tretjak, K. V. (2014), "Efektyvnist systemy marketyngu na pidpryjemstvah vynorobnoi galuzi v Ukraini”, Molodyj vchenyj, vol. 8(2), pp. 10-12

6. The official site marketing dictionary (2019), "Marketer notes", [Online], available at: http://www.marketch.ru/marketing dictionary/marketing terms s/sinkhromarketing/ (Accessed 19 April 2020).

7. Nazarova, G. G. Nazarova, G. and Hakymov, D.S. (2001), "Seasonality in Tourism: Problems and Dimensions", Visnyk DITB, vol 5, pp 60-63.

8. Nikitina, I. M. and Popova, L. O. (2003), "Substantiation of the choice of the model of seasonal adjustment of gross domestic product", Statistics of Ukraine. vol 4, pp. 20-27.

9. Djachenko, Ju. A. (2018), "Development of methods for forecasting the dynamics of exchange prices for agricultural products", Scientific Bulletin of Uzhgorod National University, pp.142-146.

10. Grynjuk, O. I. (2016), "Scientific and methodological approaches to the assessment and forecasting of the risks of oil and gas production enterprises", Bulletin of Khmelnitsky National University, pp.10-22.

11. Chetverykov, N. S. (1975), Statystycheskye yssledovanyia: Teoryia y praktyka [Statistical Studies: Theory and Practice], Nauka, Moscow, Russia.

12. Shevchenko, N. Ju. Ostankova, L. A. and Rudnev, M. Ju. (2012), "Development of conceptual approaches to the formation of a production program for production, taking into account a prediction analysis of time series", Vesnik Donbass State Power Engineering Academy, pp. 310-313.

13. Romashhenko, O. V. (2012), "Planning and forecasting of income and expenses of insurers by the method of "Analytical alignment" Problems of material culture", Economic sciences, available at: http://dspace.nbuv.gov.ua/bitstream/handle/123456789/92337/11-Romashchenko.pdf?sequence=1 (Accessed 19 April 2020).

14. Myhajlov V. S., PrylypkoJu. I. and Shepel K. I. (2012) "Seasonal fluctuations and calendar effects: separate problems in the theory and practice of statistical evaluation", Theory and methodology of statistics, vol 4, pp. 21-26.

15. Buzukova E. L. (2009) "Purchasing and suppliers. Retail Assortment Management Course", $S P b$. .: Peter, $432 \mathrm{p}$.

16. Klebanova T. S., KurzenevV. A. and Naumov V. M. (2015) "Prediction of socio-economic processes: a textbook", Kh.: KhNEU them. S. Kuznets, 656 p.

Стаття надійшла до редакиіï 20.04.2020 p. 